\title{
Energy Efficiency and Renewable Energy
}

Bringing you a prosperous future where energy is clean, abundant, reliable, and affordable

A 30 MW parabolic trough power plant located at Kramer Junction, California.

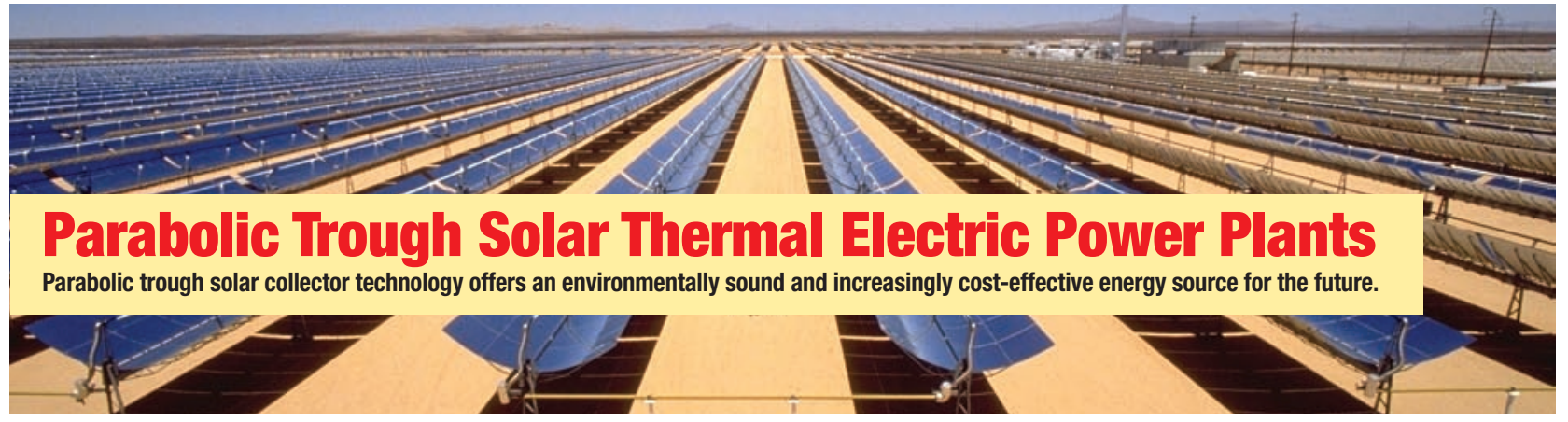

\section{U.S. Energy Supply and Solar Resource Potential}

Each year, the United States is becoming more dependent on foreign sources of energy. Already more than $50 \%$ of the oil consumed in the United States is imported. Environmental pressures to improve air quality and reduce carbon dioxide $\left(\mathrm{CO}_{2}\right)$ generation are driving a shift from coal to natural gas for new electric generation plants. Domestic sources of natural gas are not able to keep up with growing demand, causing supplies of this key energy source to become increasingly dependent on foreign imports as well. The use of natural gas as a source for hydrogen generation could further aggravate this situation in the future.

Solar energy represents a huge domestic energy resource for the United States, particularly in the Southwest where the deserts have some of the best solar resource levels in the world. For example, an area approximately $12 \%$ the size of Nevada (15\% of federal lands in Nevada) has the potential to supply all of the electric needs of the United States. In addition, solar power often complements other renewable power sources such as hydroelectric and wind power. The solar resource is typically higher during poor hydroelectric periods, and solar output peaks during the summer, whereas wind power typically peaks in the winter. Solar can complement fossil power sources as well. Eskom, the coal dominated power utility in South Africa with one of the lowest power costs in the world, has identified large-scale solar power technologies as a good intermediate load power source for its grid. Although some renewable power technologies provide an intermittent energy supply, large-scale thermal electric solar technologies can provide dispatchable power through the integration of thermal energy storage. Thermal energy storage allows solar thermal energy collected during the day to be used to generate solar electricity to meet the utility's peak loads, whether during the summer afternoons or the winter evenings. Although solar energy is abundant and free, it is a diffuse energy source, so the cost to harness (or harvest) it with solar collectors can be significant. As a result, electricity generated from solar energy is currently more expensive than power from conventional fossil-power plants. However, the Western Governors' Association has determined that even at moderate levels of deployment, large-scale solar power can potentially compete directly with conventional fossil generation. [1]

\section{Parabolic Trough Solar Power Technology}

Although many solar technologies have been demonstrated, parabolic trough solar thermal electric power plant technology represents one of the major renewable energy success stories of the last two decades. Parabolic troughs are one of the lowest-cost solar-electric power options available today and have significant potential for further cost reduction. Nine parabolic trough plants, totaling over 350 megawatts (MW) of electric generation, have been in daily operation in the California Mojave Desert for up to 18 years. These plants provide enough solar electricity to meet the residential needs of a city with 350,000 people. They have demonstrated excellent availabilities (near $100 \%$ availability during solar hours) and have reliably delivered power to help California meet its peak electric loads, especially during the California energy crisis of 2000-2001. Several new parabolic trough plants have been built or are currently under development. Growing interest in green power and $\mathrm{CO}_{2}$ reducing power technologies have helped to increase interest in this technology around the world. New parabolic trough plants are currently under construction or in the early stages of operation in support of solar portfolio standards in Nevada and Arizona and a solar tariff premium in Spain.

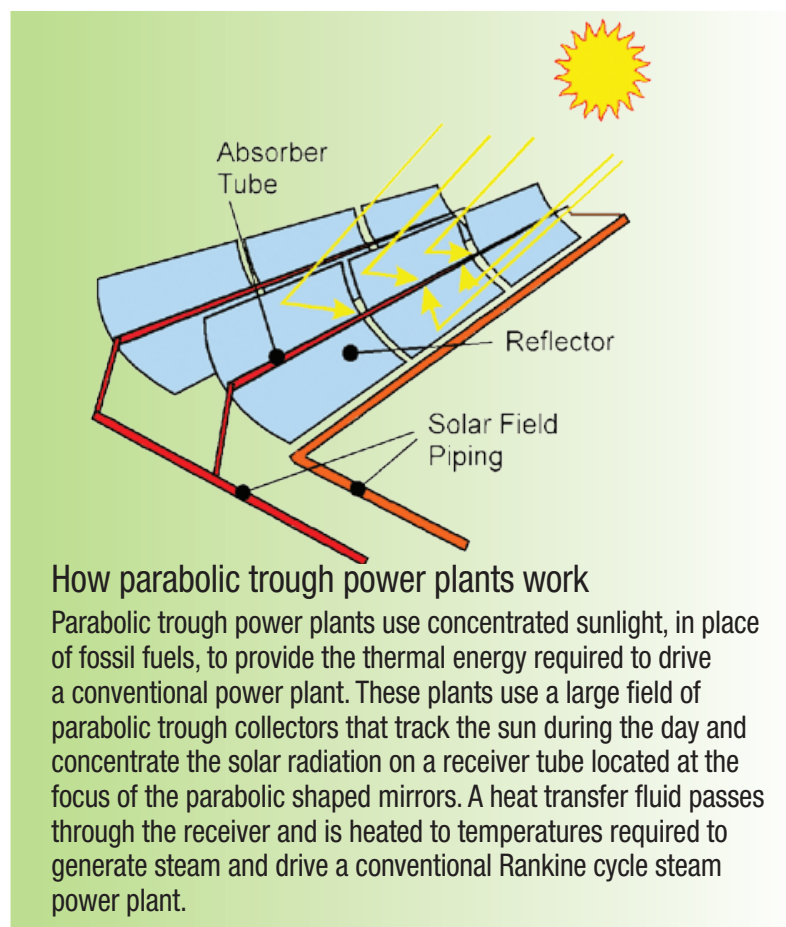




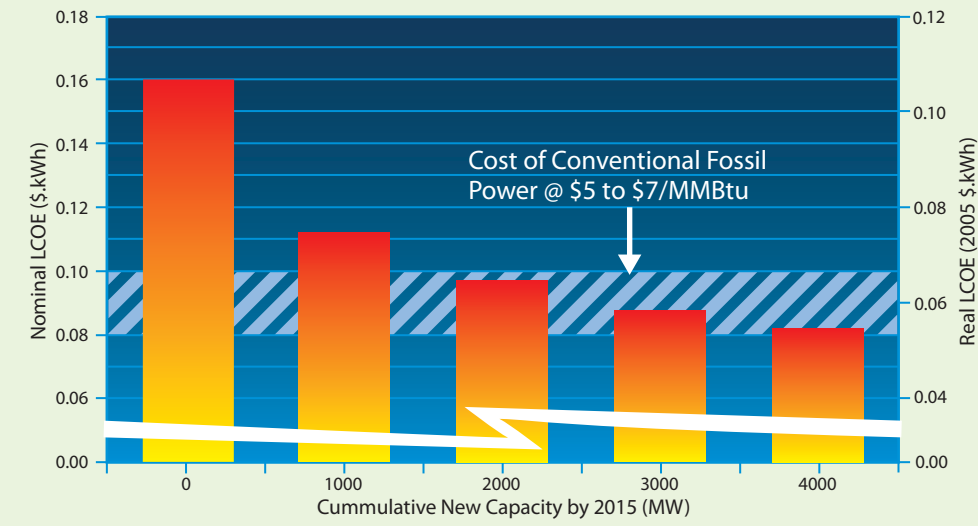

LCOE=Levelized cost of energy
Projected Cost Reduction Scenario for Parabolic Trough Technology

These projections were developed with the following assumptions:

- Trough technology with six hours of thermal energy storage

- Independent power producer Financing

- Five-year accelerated depreciation, $10 \%$ income tax credit, property tax exemption

- Includes scale-up, research and development, and learning effects

- Barstow, California site.

Data source: Western Governors' Association

\section{Reducing the Cost of Parabolic Trough Solar Power}

Parabolic trough technology has continued to advance in recent years as a result of research and development efforts by the operators of the existing trough plants, the parabolic trough industry, and government-sponsored laboratories around the world. Key advances during the last 10 years include:

- Reduction in operation and maintenance costs

- Development of improved trough receivers

- Development of improved parabolic trough concentrators

- Reduction of solar field pumping parasitics

- Development of a thermal energy storage technology for parabolic trough plants.

Although parabolic trough technology is the least-cost solar-power option available today, it is still more expensive than power from conventional fossil-fueled power plants. Recent increases in the price of natural gas have helped reduce the gap between parabolic trough solar electricity and fossil energy in the United States.

Cost Reduction Potential: At current fossil energy prices (\$5 to $\$ 7 / \mathrm{MMBtu}$ ), large-scale central solar generation must achieve costs in the range of $\$ 0.08-\$ 0.10 / \mathrm{kWh}$ (nominal) to directly compete with fossil power alternatives. The Western Governors' Association (WGA) has shown that a significant reduction in the cost of energy is possible for parabolic trough solar power. Major cost reductions are possible through the following:

- Plant scale-up: increasing the size of plants to $200 \mathrm{MW}$ or larger

- Development of advanced technologies: improved thermal storage, concentrator, and receiver designs

- Learning curve: cost reductions through plant deployments.
Based on the WGA studies, the figure above shows that parabolic trough technology appears to have the potential to begin competing directly with conventional power technologies by 2015 . In the mean time, incentives such as the current $30 \%$ income tax credit are necessary to make projects financially attractive power plant investments in initial solar. These projects will provide learning opportunities that will drive technology advances and cost reductions to make future plants directly competitive with conventional energy sources.

\section{A Solar Vision for the Future}

Solar technologies have the potential to be major contributors to the global energy supply. The ability to dispatch power allows large-scale central solar technologies to provide $50 \%$ or more of the energy needs in sunny regions around the world. In addition, because parabolic trough technology is built from commodity materials (e.g., glass, steel, and concrete) and uses standard utility power generation equipment, it is possible to scale-up and rapidly deploy new trough power plants. Also, according to a new study about the potential benefits of concentrating solar power in California, large-scale solar technologies can also provide energy price stability as well as quality jobs to the local community. [2] Solar energy has the potential to become the major new domestic energy resource in the 21st century.

\section{Sources}

[1] Western Governors' Association, Clean and Diversified Energy Initiative: Solar Task Force Report, January 2006, http://www.westgov.org/wga/initiatives/cdeac/Solar-full. pdf.

[2] L. Stoddard, J. Abiecunas, and R. O'Connell, Economic, Energy, and Environmental Benefits of Concentrating Solar Power in California, Black \& Veatch Overland Park, Kansas, Subcontract Report NREL/SR-550-39291 April 2006, http://www.nrel.gov/docs/fy06osti/39291.pdf

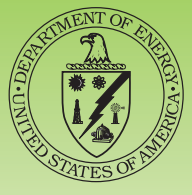

U.S. Department of Energy

Energy Efficiency and Renewable Energy

For more information contact:

EERE Information Center

1-877-EERE-INF (1-877-337-3463)

www.eere.energy.gov

Produced for the U.S. Department of Energy by the National

Renewable Energy Laboratory, a DOE national laboratory

DOE/GO-102006-2339

July 2006

Printed with a renewable-source ink on paper containing at least $50 \%$ wastepaper, including $20 \%$ post consumer waste

\section{A Strong Energy Portfolio for a Strong America Energy efficiency and clean, renewable energy will mean a stronger economy, cleaner environment, and greater energy independence for America. Working with a wide array of state, community, industry, and university partners, the U.S. Depart- ment of Energy's Office of Energy Efficiency and Renewable Energy invests in a diverse portfolio of energy technologies.}

